\title{
Effect of anticoagulants on the chromogenic Limulus lysate assay for endotoxin
}

\author{
JS MCCONNELL, J COHEN
}

From the Department of Bacteriology and Medicine, Hammersmith Hospital, Royal Postgraduate Medical School, London W12 OHS

SUMMARY We have examined the effects of anticoagulants on the chromogenic Limulus lysate assay for endotoxin. The results indicate that both heparin and CPD Adenine 1 have a striking dose related inhibitory effect on the assay. At concentrations of heparin as low as about $30 \mathrm{U} / \mathrm{ml}$ there was a $90 \%$ reduction in detectable endotoxin. The inhibitory effect of up to $100 \mathrm{U} / \mathrm{ml}$ of heparin could be neutralised by the addition of protamine sulphate.

Anticoagulants appear to be an additional factor which can adversely affect the Limulus chromogenic assay for endotoxin. This further emphasises the need for alternative approaches to the measurement of endotoxin.

In 1956 Bang reported that a lysate prepared from the amoebocytes of the horseshoe crab, Limulus polyphemus, would gel in the presence of Gram negative bacterial endotoxin.' The principle of the gelation assay proved to be activation of a primitive enzymatic coagulation cascade. ${ }^{2}$ Subsequently, synthetic chromogenic substrates developed for the human blood clotting system were used as the basis of a quantitative assay for endotoxin. ${ }^{34}$

In the course of other experiments we noted that heparin appeared to have a pronounced inhibitory effect on the chromogenic Limulus amoebocyte lysate assay. Since both we and others have found that endotoxin appears to be detected more readily in heparinised plasma than in serum ${ }^{4-6}$ we wished to investigate this apparent paradox in greater detail.

\section{Material and methods}

\section{MATERIAL AND REAGENTS}

All procedures were carried out in pyrogen free plastic ware. Plasma from a single volunteer was used throughout. Platelet poor plasma was obtained by the addition of either $20 \mathrm{U} / \mathrm{ml}$ of heparin for injection (Weddel Pharmaceuticals, London) or various concentrations of Citrate Phosphate Dextrose Adenine 1 (CPD Adenine 1) (Travenol Laboratories, Thetford, UK), followed by centrifugation at $1250 \mathrm{~g}$ for $10 \mathrm{~min}$. The endotoxin used was obtained by phenolic extraction from Escherichia

Accepted for publication 5 December 1984 coli 0127:B8 (Sigma, Poole, UK). Before assay all plasma samples were treated to remove non-specific activators and inhibitors by $1 / 20$ dilution with pyrogen free water (Antigen Ltd, Roscrea, Ireland) and heating to $60^{\circ} \mathrm{C}$ for $30 \mathrm{~min}$.

\section{ENDOTOXIN ASSAY}

Endotoxin assays were carried out as described previously ${ }^{4}$ with the following modifications: (a) Limulus amoebocyte lysate (MA Bioproducts, Walkersville, Md, USA) was used at a 1/10 dilution in pyrogen free water of the strength recommended by the manufacturers; $(b)$ the chromogenic substrate was S2423 (Kabi Diagnostica, Stockholm, Sweden).

\section{EFFECT OF HEPARIN}

Two aliquots of platelet poor plasma were spiked with endotoxin at final concentrations of $200 \mathrm{ng} / \mathrm{ml}$ and $20 \mathrm{ng} / \mathrm{ml}$. Each sample was divided into six parts of equal volume. Heparin was added to give concentrations of heparin in plasma of $500 \mathrm{U} / \mathrm{ml}, 100$ $\mathrm{U} / \mathrm{ml}, 50 \mathrm{U} / \mathrm{ml}, 20 \mathrm{U} / \mathrm{ml}$, and $10 \mathrm{U} / \mathrm{ml}$. To the sixth part was added pyrogen free water as a control; we also included a sample of unspiked, untreated plasma. Plasma samples were incubated for $30 \mathrm{~min}$ at room temperature and then assayed.

\section{EFFECT OF PROTAMINE}

The effect of protamine on the Limulus amoebocyte lysate assay was investigated by taking six aliquots of plasma containing $200 \mathrm{ng} / \mathrm{ml}$ of endotoxin and incubating with protamine sulphate (Evan's Medi- 
cal, Beaconsfield, UK) at final concentrations of 5 $\mathrm{mg} / \mathrm{ml}, 2.5 \mathrm{mg} / \mathrm{ml}, 0.5 \mathrm{mg} / \mathrm{ml}, 0.25 \mathrm{mg} / \mathrm{ml}, 1 \mathrm{mg} / \mathrm{ml}$, and $0.05 \mathrm{mg} / \mathrm{ml}$. The samples were mixed for $30 \mathrm{~min}$ at room temperature and then assayed with appropriate controls.

To determine if protamine could neutralise the inhibitory effect of heparin we took aliquots of plasma containing $200 \mathrm{ng} / \mathrm{ml}$ endotoxin and added heparin at concentrations of $1000 \mathrm{U} / \mathrm{ml}, 500 \mathrm{U} / \mathrm{ml}$, $100 \mathrm{U} / \mathrm{ml}, 50 \mathrm{U} / \mathrm{ml}, 20 \mathrm{U} / \mathrm{ml}$, and $10 \mathrm{U} / \mathrm{ml}$. Protamine was added to each sample at a concentration of $1 \mathrm{mg}$ of protamine per $100 \mathrm{U}$ heparin, the tubes incubated as above, and then assayed.

\section{EFFECT OF CPD ADENINE 1}

The minimum concentration of CPD Adenine 1 required to preserve anticoagulation was that containing $1 \mathrm{mg} / \mathrm{ml}$ sodium citrate.

Freshly drawn whole blood was separated into four parts, and CPD Adenine 1 was added at concentrations of $10 \mathrm{mg} / \mathrm{ml}, 7 \mathrm{mg} / \mathrm{ml}, 3.5 \mathrm{mg} / \mathrm{ml}$ and 1 $\mathrm{mg} / \mathrm{ml}$ sodium citrate. The plasma was obtained by centrifugation and divided into two parts. To one part was added endotoxin at a final concentration of $200 \mathrm{ng} / \mathrm{ml}$, while the second served as a control by the addition of an equal volume of pyrogen free water. The samples were then assayed.

All the experiments were performed three times.

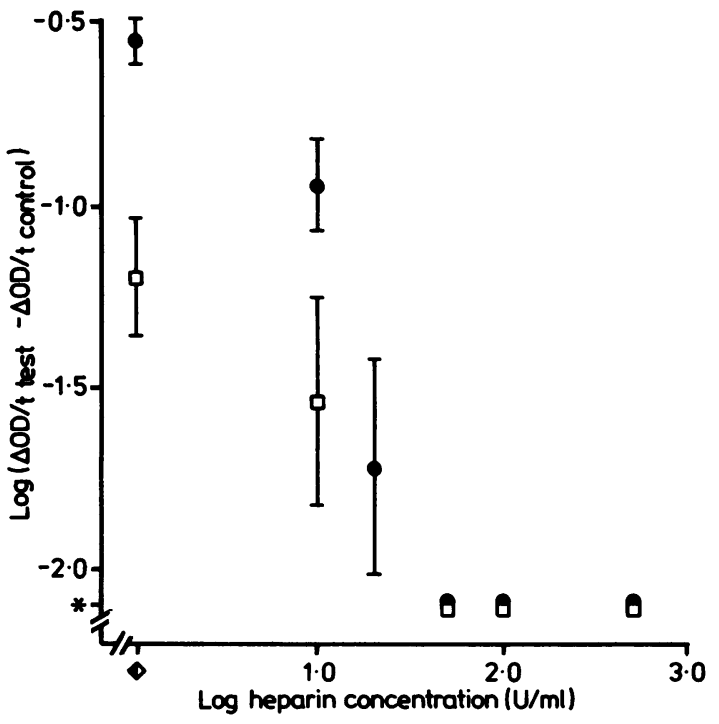

Fig. 1 Effect of adding heparin to plasma, spiked with 200 $\mathrm{ng} / \mathrm{ml}$ and $20 \mathrm{ng} / \mathrm{ml}$ endotoxin, on the recovery of endotoxin. $200 \mathrm{ng} / \mathrm{ml}$ endotoxin, $\square 20 \mathrm{ng} / \mathrm{ml}$ endotoxin, $\checkmark$ No added heparin, ${ }^{*}-\infty$ - that is, $\triangle O D / t$ test- $\triangle O D / t$ control $=0$. Bars represent standard error of the mean, $n=$ 3.

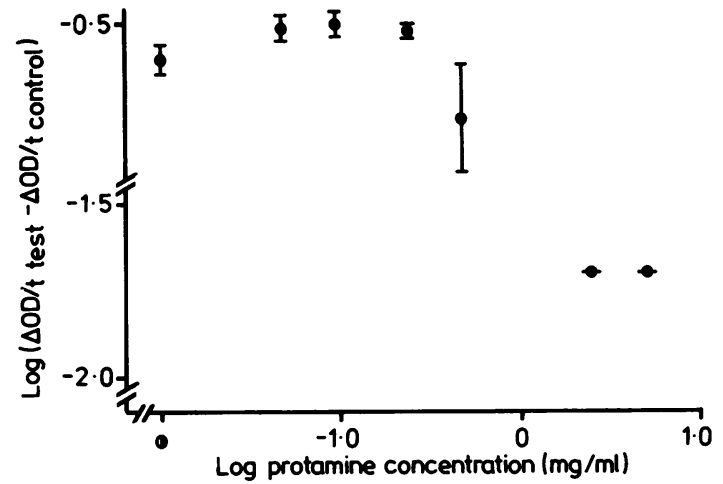

Fig. 2 Effect of adding protamine sulphate to plasma, spiked with $200 \mathrm{ng} / \mathrm{ml}$ endotoxin, on the recovery of endotoxin. 1 No added protamine. Bars represent standard error of the mean, $n=3$.

\section{Results}

Results of the endotoxin assays for each experiment are presented graphically as the log of change of optical density with time $(\Delta O D / t)$. The final log $(\Delta O D / t)$ values for each sample were calculated by subtracting the control value-that is, unspiked plasma derived from whole blood using heparin or citrate and assayed in the conventional way-from the sample value.

Fig. 1 shows that at concentrations of added heparin as low as $10 \mathrm{U} / \mathrm{ml}$ detection of endotoxin by the Limulus chromogenic assay was inhibited; with between $20 \mathrm{U} / \mathrm{ml}$ and $50 \mathrm{U} / \mathrm{ml}$ of added heparin, depending on the dose of endotoxin, the test was completely neutralised.

Adding protamine to spiked plasma (Fig. 2) almost completely inhibited the assay at $5 \mathrm{mg} / \mathrm{ml}$

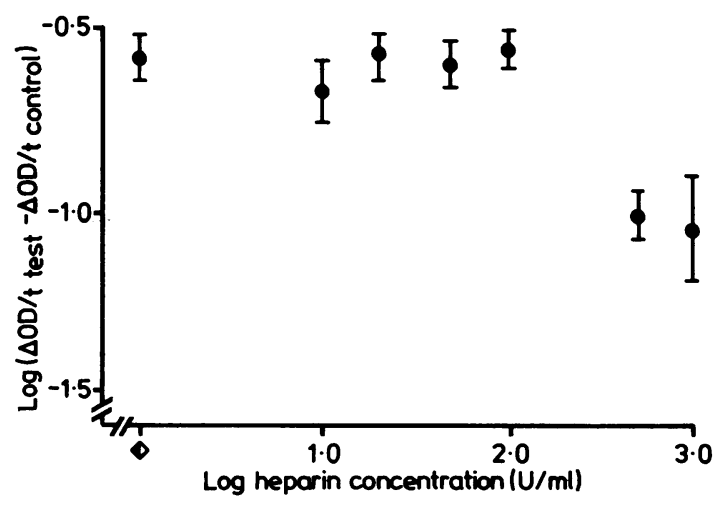

Fig. 3 Ability of protamine sulphate to neutralise the effects of heparin (see text for details). $\$$ No added heparin. Bars represent standard error of the mean. $n=3$. 


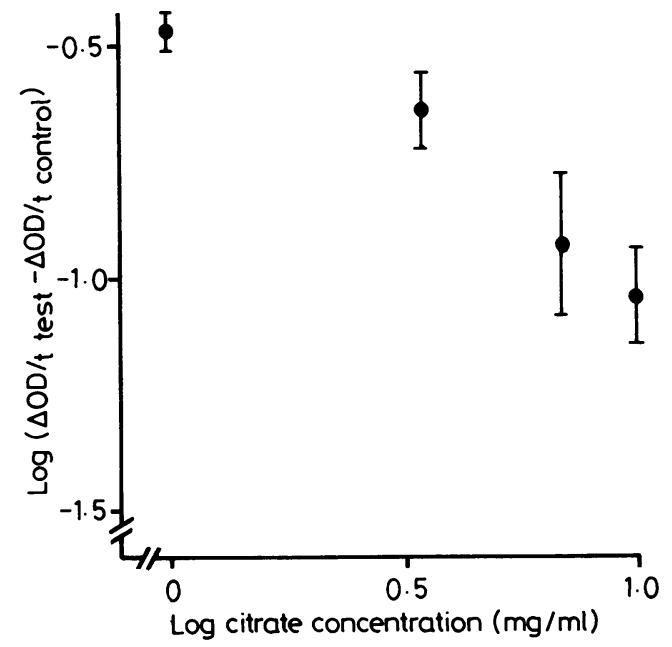

Fig. 4 Effect of various concentrations of CPD Adenine 1 (as log sodium citrate concentration) on the recovery of endotoxin from plasma spiked with $200 \mathrm{ng} / \mathrm{ml}$ endotoxin. Bars represent standard error of the mean. $n=3$.

and $2.5 \mathrm{mg} / \mathrm{ml}$ protamine, with a degree of inhibition of $0.5 \mathrm{mg} / \mathrm{ml}$ protamine.

When protamine was added to the heparinised spiked plasma (Fig. 3) at a constant level of $1 \mathrm{mg}$ of protamine per $100 \mathrm{U}$ heparin the assay remained inhibited at $1000 \mathrm{U} / \mathrm{ml}$ and $500 \mathrm{U} / \mathrm{ml}$ heparin, but the $\log (\Delta \mathrm{OD} / \mathrm{t})$ values were comparable with the control at lower concentrations of heparin.

Fig. 4 shows that the lower the concentrations of citrate used as an anticoagulant the higher the recovery of endotoxin.

\section{Discussion}

These results show that heparin and other anticoagulants can have a profound, dose related, inhibitory effect on the chromogenic Limulus amoebocyte lysate assay for endotoxin. That anticoagulants adversely effect the assay is perhaps not surprising in view of the similarity between the endotoxin mediated Limulus clotting system and the human coagulation cascade. ${ }^{2}$ There is evidence that heparin at concentrations as low as $1 \mathrm{U} / \mathrm{ml}$ is inhibitory to the Limulus amoebocyte lysate gelation assay, ${ }^{7}$ despite earlier reports which stated that doses of up to $100 \mathrm{U} / \mathrm{ml}$ of heparin had no effect on the assay ${ }^{5}$ and that values up to $200 \mathrm{U} / \mathrm{ml}$ were recommended for anticoagulation. ${ }^{8}$ These are concentrations which we have shown to be completely inhibitory in the Limulus amoebocyte lysate chromogenic assay.

It is an interesting paradox that we and others have found plasma to be the sample of choice for the recovery of endotoxin. ${ }^{49}$ In those studies a fixed concentration of heparin of $20 \mathrm{U} / \mathrm{ml}$ was used to prevent coagulation, and our results emphasise the importance of not exceeding this value if significant inhibition is to be avoided. Clinical anticoagulation is usually achieved at heparin concentrations of between 5 and $20 \mathrm{U} / \mathrm{ml}^{10}$ and may not cause a major problem.

Ideally, the effect reported here and other disadvantages associated with the Limulus amoebocyte lysate assay ${ }^{4}$ might be overcome by the development of an immunological system which recognised core glycolipid. Such studies are in progress.

We thank the Wellcome Trust for support and Avril Kirk and Sue Goodwin for typing the manuscript.

\section{References}

' Bang FB. A bacterial disease of Limulus polyphemus. Bull John Hopkins Hosp 1956;98:325-50.

${ }^{2}$ Tanaka S, Nakamura T, Morita T, Iwanaga S. Limulus anti-LPS factor: an anticoagulant which inhibits the endotoxinmediated activation of Limulus coagulation system. Biochem Biophys Res Commun 1982;105:717-23.

${ }^{3}$ Iwanaga S, Marita T, Harada T, et al. Chromogenic substances for horseshoe crab clotting enzyme. Its application for the assay of bacterial endotoxins. Haemostasis 1978; 7:183-8.

${ }^{4}$ Cohen J, McConnell JS. Observations on the measurement and evaluation of endotoxinaemia by a quantitative Limulus lysate microassay. J Infect Dis 1984; 150:916-24.

${ }^{5}$ Levin J, Tomasulo PA, Oser RS. Detection of endotoxin in human blood and demonstration of an inhibitor. J Lab Clin Med 1970;75:903-11.

- Ditter B, Becker K-P, Urbaschek R, Urbaschek B. Detection of endotoxin in blood and other specimens by evaluation of photometrically registered LAL-reaction kinetics in microtiter plates. Prog Clin Biol Res 1982;93:385-91.

' Sullivan JD, Watson SW. Inhibitory effect of heparin on the Limulus test for endotoxin. J Clin Microbiol 1975;2:151.

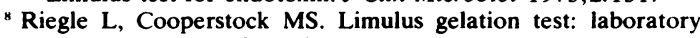
considerations. Lab Med 1977;8:28-30.

' Harris RI, Stone PCM, Stuart J. An improved chromogenic substrate endotoxin assay for clinical use. J Clin Patho 1983;36:1145-9.

${ }^{10}$ Thomas DP. The management of pulmonary embolic disease Am J Med Sci 1970;259:157-63.

Requests for reprints to: Dr J Cohen, Department of Bacteriology, Royal Postgraduate Medical School, Hammersmith Hospital, Ducane Road, London W12 QHS, England. 